\title{
Editorial
}

\section{Imams and Fighting Radicalism in North America}

Indeed God enjoins justice and doing of good (virtue) and giving to kinsfolk, and He forbids all that is shameful (lewdness), and abomination (evil), and aggression (wickedness): He admonishes you so that you might remember. (Qur'an 16:90)

More than 90 percent of practicing Sunni Muslims are likely to hear this verse recited to signal the end of Friday khutbah. Rightly identified as embodying God's specific admonition to Muslims, and as one that is worth constant pondering, this verse is cited regardless of the khutbah's topic partly to imprint its message on the attendees' minds. In this editorial, however, I use it specifically within the context of religious radicalism as regards both its message and historical application.

This very comprehensive verse is loaded with interpersonal values as well as communal principles. Ibn Mas `ud, the young Companion famous for his knowledge of the Qur'an, describes it as "the most encompassing verse, in the entire Qur'an, pertaining to good and evil" (ajma 'ayatin fi al-Qur'an li khayr wa sharr). ${ }^{1}$ It is as categorical in its admonition of justice and fairness, kindness and generosity, attention and offerings to relatives as it is clear in its prohibition of shameful acts and lewdness, abomination and evil, and aggression and wickedness. According to Ibn Ashur, these are specific to the Shari'ah's general principles (usul) of enjoining good and forbidding evil. ${ }^{2}$ Were people to lead their entire lives not only cognizant of these elements but also according to each admonition, they would create a perfectly harmonious society.

With regards to fighting radicalism, I use the above verse not solely for what it says (although pondering them is ever desideratum), but mainly for how generations of imams have utilized it on Fridays. The results of such a survey are, however, rather disappointing, for the contents, style, and manner of delivering the verse fail to serve as a "magic bullet," at least in attract- 
ing the listeners' attention, let alone have the intended impact. This is not to say that Muslim congregations or individuals ignore the Qur'an's injunctions. But the irony remains that while many Muslims do not understand what and why it is said, most of those who do understand it seem not to hear it well or pay proper attention to its message. As intimated above, it always signals the "wrapping up" of the sermon, which usually closes with a supplication; however, some can hardly separate it from the verse, as the latter is recited immediately after the former. Some non-Arab Muslims seem to assume that the verse is part and parcel of the supplication, as they usually continue to hold up their hands as it is read.

When discussing how radicalizing messages, herein defined as those that lead to extremist and violent tendencies, are disseminated and how to propose solutions, broader geographic differences have to be considered, for the Muslim community is not monolithic. For example, Muslims in North America do not hear radicalizing messages from the pulpits, ${ }^{3}$ as such a practice is unacceptable both to them and to the authorities, who stand ready to take anybody to task for that. "[I]ndeed, it was a Muslim vendor who [first] tipped off the police about the suspicious SUV in Times Square, a fact that remains unknown to most Americans." " In fact, the difficulty is that Muslims who show that they are good citizens are hardly ever recognized as such; in fact, by doing so they might actually become suspects themselves.

A message from the pulpit, for instance, that expresses sympathy for the Gazans following the 2008 invasion may not necessarily be a radicalizing one. Of course, just what constitutes a radicalizing message is in the eyes of the beholder. But the lines are so easily blurred that any such message, despite its sincerity, may simply be construed as radicalizing the congregation. But while Muslims are able to make this differentiation, this is not necessarily the case with other people, and hence the misplaced accusations that Muslims are sympathetic to "radicalization."

Despite this general peaceful tendency among Muslim North Americans, it seems undeniable that there are a few individual radicals. Although sermons are not responsible for their radicalization - if this were the case, there would be large numbers everywhere - I believe that sermons can be used to thwart or offset those so inclined, if not to impact the would-be radicals directly (who may or may not be attending regular prayers), at least to alert and discourage any potentially naïve and innocent conspirators.

Sympathizers and critics of Islam analyze the "terror" suspects' level of devotion and religious participation (or lack thereof) in an effort to either 
exonerate or vilify imams for the actions of some radicals. These efforts are mainly baseless speculations, for several variables outside the mosque also account for one's radicalization. Irrespective of any perceived socioeconomic deprivation and religio-political aggravation, the larger Muslim community needs to be educated in such a way that strips radicalism of its potential appeal and acceptability. To think that radical tendencies can be completely eradicated, either by Muslims or the West's military and security apparatus is both naïve and ahistorical.

Just as people like Timothy McVeigh and members of the Hutaree militia group exist in America - for some reason they are not considered "terrorists" - there will always be some Muslims who will be radicalized by what they perceive to be wrong. This is just one of the more compelling reasons why imams must strive to heighten their rhetoric against radicalizing tendencies and to promote peaceful coexistence by directly addressing Islam's opposition to violence and radicalism. They must get in the habit of dedicating entire speeches and sermons, regardless of the occasion, to discouraging any form of radical tendencies and their harmful consequences on humanity at large. Most importantly they must, in the manner of the verse's usage, constantly highlight how radicalism and terrorism are un-Islamic and must not be condoned or supported at the end of every sermon. Just like the verse, this message must be delivered regardless of the sermon's subject in order to inundate and bombard the congregation with this message.

It would, however, be a mistake for the imams to do this simply to appease critics or governments, for gradually their hypocrisy would become clear and thus defeat the whole effort. As sincerity is key to all of a Muslim's actions, its absence may not only prove fruitless in the eyes of God but also appear repulsive to Muslims, whose support and compliance are crucial. Hence, imams must be sincere when explaining the negative impact of religious radicalism both to the Muslim community and humanity at large. The context and reasons for their new approaches must be explained so that their congregations will understand the urgency of their message. All of this is based on the assumption that imams are well-educated, sincere in educating their congregations, and free of radical tendencies. As part of their job description, they are also presumed ready to confront any evil tendencies and activities from all quarters and segments of human society.

The activities and arguments of the established international radical groups and their leaders do not make the local imams' work any easier. Yet the latter must disprove and dispel the arguments of the former, who not only distort the Qur'an and the Sunnah but also manipulate real historical facts 
and socioeconomic circumstances to convince and recruit members via the new media. ${ }^{7}$

Now to the verse's historical usage and how it relates to combating radicalism. The genesis of placing 16:90 at the end of the Friday sermon is the result of the Umayyad caliph Umar ibn Abd al-Aziz's (d. 720) insight and motivation. Until he ascended the throne, there had been an Umayyad tradition of having the imams shower insults on the great Companion Ali ibn Abi Talib (d. 661), a caliph, the Prophet's cousin and son-in-law, as well as the Shi'ah community's first Imam. Upon assuming the caliphate, Umar ibn Abd al-Aziz ended that practice and replaced it with reciting 16:90. ${ }^{8}$ This tradition has remained in force among Sunni Muslim communities ever since.

Muslims can learn at least two lessons from this incident. The first one is that Islam rejects all forms of radicalism. Ibn Abd al-Aziz broke with his dynasty's tradition to end an obviously un-Islamic and radical practice. Regardless of Ali's religious credentials and his family ties to the Prophet, insulting any Muslim in such a manner is an extremist tendency, one that should be unthinkable in the case of Ali. The main reason for such a reprehensible practice was political. Even if it were religious, however, it would still be unacceptable. Ibn Abd al-Aziz, on the other hand, reasoned that he was heeding God's command and started this new practice so that Muslims would ponder 16:90 and begin to apply it in their own lives.

The second lesson is how the verse's recitation was instituted. As intimated above, its content or the message being delivered must be "forced" on Muslims. What could be more effective than making it the last thing they hear during the Friday's sermon? This is why I propose that all imams construct their own anti-radicalism message and make it the last thing their congregations hear, regardless of the sermon's subject matter. This new approach will, hopefully, cause generations of Muslims to imbibe the Qur'an's wisdom and consider radicalism utterly unacceptable, even if it only occurs with isolated psychopaths.

We, at AJISS, will be glad to receive articles that trace, in a rigorous, academic, and unbiased fashion, the issue of religious radicalism among Muslims around the world.

This issue of AJISS opens with Malik Mufti's "The Many-Colored Cloak: Evolving Conceptions of Democracy in Islamic Political Though." Based on textual sources and interviews, the author analyzes some key decisions related to electoral participation made by Turkey's AK Party and the Muslim Brotherhoods in Egypt, Jordan, and Syria. The article focuses on these movements' gradual embrace of three key democratic principles: plu- 
ralism, the people as the source of political authority, and the legitimacy of such procedural mechanisms as multiple parties and regular elections. Mufti concludes that democratic discourse has already become hegemonic among mainstream Islamist movements in Turkey and the Arab world.

Yasien Mohamed follows with his "The Islamic Ideology of Ali Shari'ati." Mohamed attempts to provide answers to certain crucial questions that bring to fore the essence and significance of Shari'ati's Islamic ideology as it affects Iranian society. They include the following: Why did Shari'ati appeal to students and intellectuals? What philosophical and theological elements make up his Islamic ideology, his Islamic sociology, and his concept of struggle (jihad)? How did he manage to blend Shi'ite theology and Marxist dialectical materialism to produce his own brand of Islamic ideology? Is the role of the sociologist to describe or to transform society?

Next is "When Words Collide: Islam and Modernity - Alternative Paradigms, Contrasting Authentic Ideals" by Aslam Farouk-Alli. Using the issue of freedom of expression as an entry point, Farouk-Alli examines the contrasting cultural conduits that define Muslim and western societies by outlining the main tropes of their worldviews. He seeks to suggest an alternative engagement between Islam and the West, one that emphasizes convergence over conflict. This stems from his conclusion that this presumed conflict between the two is rooted in contrasting worldviews informed by alternative moral underpinnings and differing existential implications.

The final article, "The Economic Ideas of Shah Wali-Allah al-Dihlawi," comes from Abdul Azim Islahi. He analyzes some of the socioeconomic theories put forward by Shah Wali-Allah, which some readers may find fascinating and relevant. Islahi studies how al-Dihlawi treated the economic problems of his time; reflected upon the economy's applied aspects; and such theoretical issues as a person's basic occupation, the need for a division of labor, the nature and function of money, and undesirable economic practices. Finally, the author explains al-Dihlawi's formulation of irtifaqat (the stages of socioeconomic development), the theory around which his economic ideas revolve.

In conclusion, we are confident that once again we have assembled a collection of fine studies and thought-provoking articles for our readers, who will surely find them intellectually stimulating.

The thirty-ninth annual conference of the Association of Muslim Social Scientists of North America (AMSS) will be held at DePaul Univeristy (Chicago) on 25 September 2010. Speakers will engage themes related to the study of Islam and Muslim societies that address global citizenship, reli- 
gious and cultural pluralism, transnational activism, social movements, dialogical encounters and solidarity as they are shaped within the global postmodern context and the related politics of global war, militarism, securitization, and neo-liberalism.

Our next issue will deal with Islamic ethics and its relevance to contemporary debates on bioethics, the environment, and evolution. Hamid Mavani argues that ijtihad in Shi' $i$ legal theory enables it to adapt to changing contingencies and circumstances. David Solomon Jalajel explores the distinctions made by classical Islamic theologians between God's actions and human actions and their potential to address ethical objections to evolution. Ali M. Rizvi proposes the plausibility of a philosophically viable yet religiously oriented environmental ethics, and Marie-Luisa Frick analyzes the potential of Islamic ethics to revitalize the idea of human rights.

\section{Endnotes}

1. Al-Razi, Tafsir al-Kabir (Beirut: Dar al-Kutb al-'Ilmiyyah, 2000), 20:81.

2. Ibn Ashur, Tafsir al-Tahrir wa al-Tanwīr (Beirut: Mu'assasat al-Tarikh, 2000) 13:204, 208.

3. One cannot, however, say with certainty about what goes on in the basement or garrage of every Muslim's home.

4. See www.huffingtonpost.com/kamran-pasha/the-mosque-by-ground-zero b 578146.html?view=screen; http://www.democracynow.org/2010/5/6/muslim = vendor_gets_no_credit_in.

5. Ibid.

6. See www.adl.org/learn/ext us/militia m.asp?xpicked=4\&item=19; www.detnews.com/article/20100413/METRO/4130370; and www.detnews.com/article/ 20100429/METRO/4290479.

7. Gilles Kepel and Jean-Pierre Milelli, eds., Al-Qaeda in Its Own Words, trans. Pascale Ghazaleh (Cambridge, MA \& London: Harvard University Press, 2008).

8. Ibn Ashur, Tafsir, 13:208-09.

Zakyi Ibrahim

Editor zibrahim@,fullerton.edu 